\title{
Dietary whey protein lessens several risk factors for metabolic diseases: a review
}

\author{
Gabriela TD Sousa ${ }^{1}$, Fábio S Lira², José C Rosa', Erick P de Oliveira ${ }^{3}$, Lila M Oyama ${ }^{4}$, Ronaldo V Santos ${ }^{5}$ and \\ Gustavo D Pimentel $\left.\right|^{6^{*}}$
}

\begin{abstract}
Obesity and type 2 diabetes mellitus (DM) have grown in prevalence around the world, and recently, related diseases have been considered epidemic. Given the high cost of treatment of obesity/DM-associated diseases, strategies such as dietary manipulation have been widely studied; among them, the whey protein diet has reached popularity because it has been suggested as a strategy for the prevention and treatment of obesity and DM in both humans and animals. Among its main actions, the following activities stand out: reduction of serum glucose in healthy individuals, impaired glucose tolerance in DM and obese patients; reduction in body weight; maintenance of muscle mass; increases in the release of anorectic hormones such as cholecystokinin, leptin, and glucagon like-peptide 1 (GLP-1); and a decrease in the orexigenic hormone ghrelin. Furthermore, studies have shown that whey protein can also lead to reductions in blood pressure, inflammation, and oxidative stress.
\end{abstract}

Keywords: Whey protein, Obesity, Type 2 diabetes mellitus, Appetite, Inflammation, Hypertension.

\section{Introduction}

Excess bodyweight in humans has been increasing worldwide. It is considered an epidemic by the World Health Organization (WHO) [1,2]. Recently, it was estimated that more than 300 million people worldwide are obese and more than 1 billion are overweight [3].

Similar to obesity, type 2 diabetes mellitus (DM) has been regarded as a major global epidemic of the $21^{\text {st }}$ century [4]. In addition, obese individuals twice as likely to develop metabolic syndrome (MS) comorbidities [5].

Obesity and DM are MS-associated diseases. Although the pathogenesis of MS and each of its components is complex and poorly understood, abdominal obesity and insulin resistance are recognized as risk factors for MS. Furthermore, patients with MS have a five-fold higher risk of developing DM [6].

Patients with DM have an elevated response to postprandial triacylglycerols compared to non-diabetic subjects. Additionally, postprandial triacylglycerols are also

* Correspondence: gupimentel@yahoo.com.br

${ }^{6}$ Departamento de Clínica Médica, Universidade Estadual de Campinas (UNICAMP), Campinas/SP, MA: 13083-970, Brazil

Full list of author information is available at the end of the article known to be strongly associated with cardiovascular diseases [7].

Reductions in body weight can reduce obesity-related problems [8-10]. Accordingly, dietary manipulations may promote increased satiety, to stimulate the anorexigenic hormones and consequent to reduce food intake and body weight [11]. Therefore, is extremely important to discover strategies that maximize the effect of weight loss and inhibit weight regain after short- and long-term of nutritional counseling $[2,12,13]$. Likewise, diet supplementation with milk serum protein has been suggested as an adjunct strategy in the prevention and treatment of obesity and MS-related diseases in humans $[14,15]$ and animals $[16,17]$. In addition, dietary milk serum proteins, e.g., whey protein, have high nutritional value because it contains all essential amino acids in higher concentrations than vegetable protein sources $[18,19]$. Based on that, this review aims to discuss the main effects of whey protein in the treatment or prevention of obesity, DM, hypertension, oxidative stress and MSlinked metabolic complications.

\section{Methodology}

For the preparation of this review, we performed bibliographic searches in databases of the CAPES Periodic

\section{Biomed Central}


Portal, Scielo, and Medline/Pubmed, covering articles published between 2003 and 2012. A search of articles was made using the key words "whey protein," "milk serum protein," "type 2 diabetes mellitus," "obesity," "insulin resistance," "inflammation," "hypertension," "metabolic syndrome," and "protein hydrolysates."

\section{Main nutritional and functional components of whey protein}

Milk serum proteins are defined as substances that remain soluble in milk serum [20]. These proteins are naturally formed during the production of cheese $[19,21]$ and account for $20 \%$ of the all protein in milk [21-23], such as $\beta$-lactoglobulins, $\alpha$-lactalbumin, immunoglobulins, lactoferrin, lactoperoxidase, glycomacropeptide, bovine serum albumin [18,20,22,24], and other proteins [22].

In addition, whey protein has high concentrations of branched chain amino acids (BCAAs), such as leucine, isoleucine, and valine, which are also related to important factors for muscle growth, build, and repair [14,25].

Milk serum proteins do not coagulate in acidic conditions; they resist the action of quimosine from the stomach, quickly reach the jejunum [19], are rapidly digested, and raise plasma amino acid concentrations of $[21,26]$. Therefore, milk serum proteins perform several functions, such as mineral absorption, improvement of protein synthesis, sensitivity to hormones, and decreased blood glucose and lipid levels [7,15,16,21,23,27-29]. In summary, the main nutritional and functional components of whey protein are presented in Table 1.

\section{Improvement risk factors for metabolic diseases Obesity}

Several types of diets are being studied to find a model that has the quality and quantity of nutrients to promote weight loss, reduction of body fat, maintenance of muscle mass and satiety control [10,13,14,29,35-37].

Frestedt et al. [10] demonstrated that the supplementation with a mixture of whey protein isolate with other peptides ( 2 servings/day and each serving with $10 \mathrm{~g}$ protein) for 54 healthy subjects for 12 weeks, in addition to 47 control subjects who consumed glucose (10 g/serving) led to weight loss in both groups, but the group supplemented with whey protein had higher weight loss. They also had greater reductions of body fat $(6.1 \%)$ and a higher maintenance of lean mass than the control group who had consumed just glucose.

Pilvi et al. [13] studied mice that had diet-induced obesity and were subsequently fed a low-calorie diet with different types of proteins (whey protein isolate, $\alpha$-lactalbumin, $\beta$-lactoglobulin, and lactoferrin) for 50 days, and after this period, they returned to high fat diet. The mice that consumed $\alpha$-lactalbumin (45.9 g) had a significant loss of fat mass during the caloric restriction period and a reduction in visceral fat during the weight recovery period when compared to other groups. But this is not a conclusive explanation about the mechanisms that lead to such results.

Another component of milk, calcium, has been extensively studied with a possible anti-obesity role. But Pilvi et al. [29] observed a significant decrease in weight gain and body fat and a higher fat excretion in mice fed for 21 weeks with high-fat diet (60\% of total calories from fat), $18 \%$ protein (whey protein isolate), and $1.8 \%$ calcium carbonate $\left(\mathrm{CaCO}_{3}\right)$ in comparison with a similar diet that had casein as the protein source. The authors suggest that a possible explanation for this result is the high levels of leucine present in the whey protein, e.g., the leucine may modulate insulin signaling by phosphatidylinositol 3 kinase (PI3K) directing the energy to muscle synthesis and not for storage in adipose tissue.

Table 1 Main components and actions of whey protein

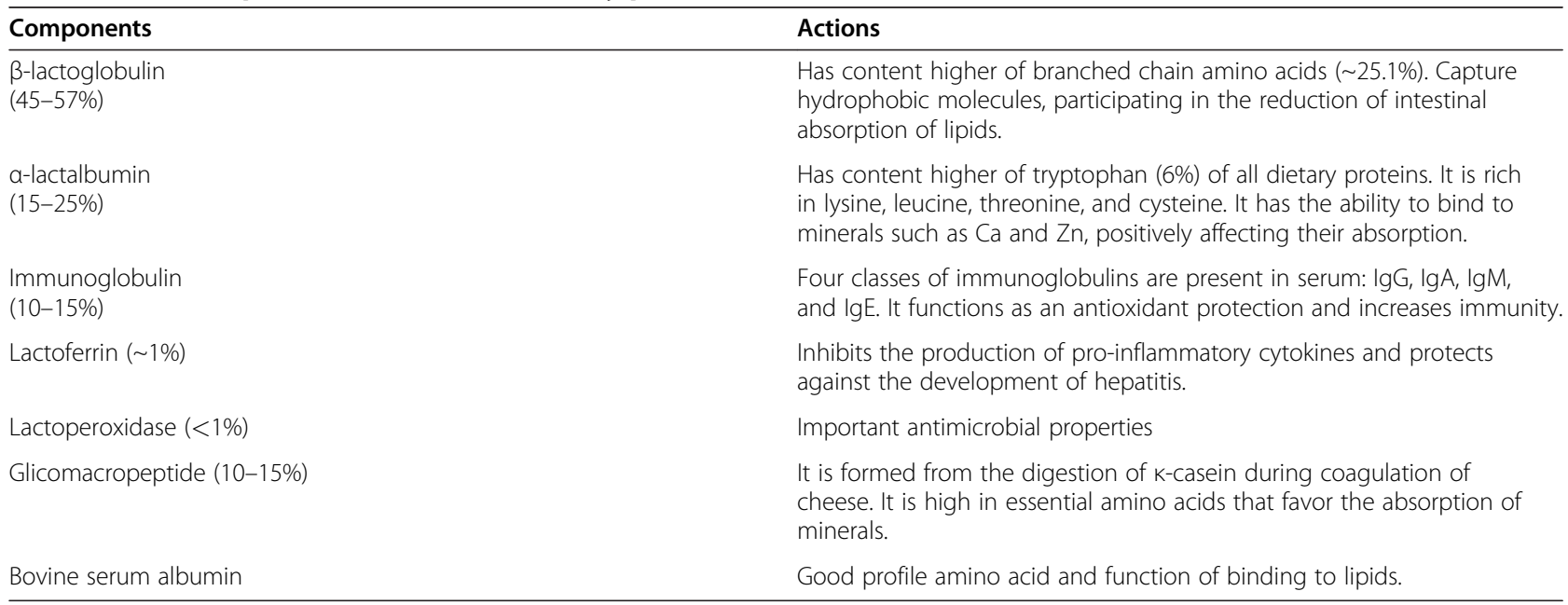


Subsequently, Pilvi et al. [38] showed that mice that consumed a high-fat diet (60\% of total calories from fat) with $18 \%$ protein (whey protein isolate) and $1.8 \%$ calcium carbonate for 12 weeks had not only an inhibition in the accumulation of fat mass but also an increase in gene expression in the visceral adipose tissue of leptin and $\beta 3$-adrenergic receptor when compared to another group of mice that received a diet with similar fat and protein contents, that instead used casein instead of whey and only $0.4 \%$ calcium carbonate. Thus, the authors suggest that the whey protein isolate may reduce obesity via improvement of leptin sensibility.

Baer et al. [35] showed that the type of protein can influence the weight loss response. Supplementation with $56 \mathrm{~g}$ of whey protein (consumed twice daily) for 23 weeks diminished body weight and fat mass when compared with the group that consumed just carbohydrates. Moreover, waist circumference and fasting ghrelin levels were lower in the whey protein group when compared to the group that ingested soy protein. These results demonstrated that through yet-unknown mechanisms, different sources of dietary protein may differentially facilitate weight loss and affect body composition.

In addition to the type dietary of protein, the proportion of nutrients also influences energy consumption and body composition [37]. Pichon et al. [37] observed a reduction in body weight and adipose tissue in rats after 25 days of consuming a high-protein diet (55\% of total energy intake) compared to rats that consumed a normal protein diet (14\% of energy). In addition, the results were more pronounced with the high protein diet containing whey protein isolate enriched with $\beta$-lactoglobulin compared with other protein sources, such as whole milk and whey protein concentrate. The authors suggested that these results were obtained because the proteins have a greater power of satiety when compared to the other nutrients. Moreover, $\beta$-lactoglobulin may capture hydrophobic molecules, decreasing the absorption of fat by intestinal cells. Furthermore, a high protein diet induces to increases in thermogenesis [20].

Furthermore, the reduction of body weight and body fat [9] and the decrease of serum triacylglycerols levels in obese individuals are extremely important, since these individuals are at increased risk for cardiovascular diseases [23,26]. Recently, Mortensen et al. [7] showed a decrease in triacylglycerol levels when whey protein was supplemented in DM patients. In addition, Pal et al. [23] confirmed these results in both overweight and obese post-menopausal women. This reduction was found after consumption of $45 \mathrm{~g}$ of whey protein isolate together with a high-fat meal when compared to consumption of the equivalent amount of glucose or casein. Pal et al. [39] also showed a decrease in triacylglycerol concentration in both overweight and obese individuals after
12 weeks of supplementation with $54 \mathrm{~g}$ of whey protein compared to control group (without supplementation) and with consumption of the same amount of glucose. As a reduction of $\sim 20 \%$ in serum triacylglycerols has been shown to reduce the progression of coronary diseases, these results are very important to decreasing obesity.

Kasim-Karakas et al. [40] studied the influence of the ingestion of whey protein in overweight and obese women with polycystic ovary syndrome (PCOS). It has been known that a reduction in body weight improves the symptoms of PCOS. Accordingly, the intake of $75 \mathrm{~g}$ of whey protein isolate compared to $75 \mathrm{~g}$ of glucose reduced the ghrelin levels for 5 hours after consumption. Therefore, these results also suggest that the whey protein can prolong satiety.

Recently, Pal and Ellis [41] showed in overweight and obese individuals that supplementation of whey protein (54 g) for 12 weeks did not significantly reduce the body weight, BMI, waist circumference, and total body fat, but decreases the triacylglycerol and insulin levels after treatment.

Collectively, these studies that relationship whey protein and obesity showed improvement in insulin sensitivity and lipid profile with possible increase of energy expenditure.

\section{Type 2 diabetes mellitus}

Although insulin is a hormone anorectic [42-45] and suppresses ghrelin [40], it is also an anabolic hormone and therefore is related to increases in muscle protein synthesis [42]. Furthermore, hyperinsulinemia inhibits hormone sensitive lipase (HSL), suppressing the release of fatty acids from adipose tissue [7] and stimulates the lipoprotein lipase (LPL) and fatty acid synthesis, contributing to obesity [40]. However, the increase in insulin levels after consumption of whey protein reported in several studies is not able to promote the increase of fat mass, perhaps due to the high leucine contents present in whey protein and also because its consumption over the long-term (>12 weeks) improves insulin sensitivity [41].

Recent studies have shown the important role of whey protein supplementation in glycemia control, possibly through the stimulation of incretin hormones, which increase fasting and postprandial insulin release and improve insulin sensitivity [41,46-48].

Pichon et al. [37] showed that a high-protein diet raises insulin concentrations compared to a normoproteic diet. However, in human and rat studies in which the protein is combined with carbohydrate, an increase in the insulin response has been observed [14-16]. In addition, whey protein stimulates insulin secretion, and when compared to casein, milk serum proteins have 
increased postprandial insulinotropic effects that are probably mediated by the rapid serum absorption of BCAAs, the improvement in glucose homeostasis in $\mathrm{DM}$, and the possible delay or withdraw of the medicine [46] .

Recently, Gunnarsson et al. [16] showed the effects of acute administration of whey protein plus glucose by nasogastric tube (enteral diet) in mice when compared to the administration of only glucose. In this study, the authors found an increase in insulin levels three times greater and an insulin tolerance four times greater with consumption of whey protein.

Petersen et al. [15] observed in healthy subjects a significant reduction in postprandial glucose $(37.5 \%)$ when consumed in a single dose containing $50 \mathrm{~g}$ of carbohydrate plus milk serum proteins (20 g in total). This decrease was dose-dependent; thus, the higher the protein intake, the greater its effect on blood glucose. The same effect was observed by Frid et al. [46] in DM subjects that consumed milk serum protein. In this study, the authors found a significant increase in insulin and glucose-dependent insulinotropic peptide (GIP).

Recently, Mortensen et al. [7] confirmed the hypoglycemic effect of whey protein in individuals with DM within eight hours of consuming a meal test that contained $45 \mathrm{~g}$ of whey protein compared to three other meals containing different protein sources, casein, gluten, and codfish. Moreover, within six hours of a meal test a reduction in triacylglycerol concentrations was observed with the supplementation of whey compared to three other meals that contained a different type of protein. Interestingly, all protein meals were associated with a high-fat diet (100 g of butter).

Lan-Pidhainy and Wolever [28] also observed a significant hypoglycemic effect in individuals with insulin resistance after the consumption of a drink containing $30 \mathrm{~g}$ of whey protein plus $50 \mathrm{~g}$ of glucose compared to groups of individuals who consumed only $50 \mathrm{~g}$ glucose or another group who consumed $50 \mathrm{~g}$ of glucose plus $30 \mathrm{~g}$ of canola oil.

Studies performed in rats $[16,17]$ showed that supplementation with whey protein possibly suppressed serum glucose level by the inhibition of the enzyme dipeptidyl peptidase-IV (DPP-IV), whose function is to disable the incretin hormones, such as GLP-1 (glucagon-like peptide 1) and GIP, which are both related to glycemic control. Gunnarsson et al. [16] suggest, in mice, that the digestion of whey protein leads to the formation of di- and tri-peptides that are a substrate for DPP-IV. Nevertheless, Frid et al. [46] and Mortensen et al. [7] found no changes in blood GLP-1 levels, only decreased glucose levels after consumption of different amounts, 36.4 g and $45 \mathrm{~g}$ of whey protein in DM individuals. These findings may possibly occur because, in diabetic subjects, the secretion postprandial GLP-1 is decreased $[15,49]$ and the enzyme activity DDP-IV is increased [50].

In healthy individuals, an increased GLP-1 levels due to consumption of whey protein is more palatable [51]. Recently, Veldhorst et al. [51] observed an increase in blood insulin (91\%) and GLP-1 (164\%) levels after consumption of a diet containing $25 \%$ of calories from protein (whey protein), 55\% from carbohydrates, and 20\% from lipids compared to similar quantities of casein. In addition, non-significant reduction of blood glucose with the consumption of whey compared to casein was observed.

In summary, protein is important in fetal growth and development of the pancreas. Furthermore, adaptations to nutritional stress may permanently alter the physiology and metabolism of several organs, leading to longterm diseases such as cardiovascular diseases, DM, and MS [24]. Likewise, Barnett et al. [24] observed reduction of $55-65 \%$ in insulin secretion in adult life in the offspring of mother rats who consumed low amounts of protein (whey protein) during pregnancy. This reduction is related to the early development of DM in adult humans.

Therefore, whey protein may be utilized by reduce insulin resistance due the increase in secretion of GLP-1 and to reduce serum glucose and insulin levels.

\section{Hypertension}

Hypertension is commonly found in patients with DM and may affect approximately $60 \%$ of Brazilian individuals [52].

Recently, it was discovered that diet is a major determinant of blood pressure. Likewise, certain foods have a direct role in the reduction of blood pressure or additional reductions in cardiovascular mortality [41,53]. Some amino acids of the whey protein, e.g., $\alpha$-lactalbumin and $\beta$-lactoglobulin, are precursors of peptide inhibitors of angiotensin-converting enzyme (ACE) [20]. $A C E$ is a key enzyme in the regulation of blood pressure [41].

Pal and Ellis [41] showed the hypotensive effect that occurs after intake of whey protein (54 g protein) and casein (27 g protein) in either obese or overweight normotensive individuals. However, the components of proteins that could possibly lead to the improvement of blood pressure were not analyzed in this study. Likewise, Lee et al. [54] found no decrease in blood pressure in individuals with mild hypertension who consumed a drink containing skim milk with milk serum proteins $(125 \mathrm{~mL})$ for 12 weeks. The low level of peptides $(2.6 \mathrm{~g}$ per $100 \mathrm{~g}$ of protein drink) administered together with protein may have been responsible for the absence of an effect on blood pressure. 
In summary, whey protein is associated with reduction blood pressure by inhibition of ACE enzyme and possibly via lower body weight gain in individuals that habitually consumed the aminoacids from whey protein or BCAA than those subjects that consumption others aminoacids, for e.g. non essential. Therefore, whey protein can in the future be considered extremely important for the control of hypertension.

\section{Possible mechanisms involved in reducing risk factors for metabolic diseases \\ Reduction of food intake}

Satiety is an important factor in the regulation of food intake and also in the control of obesity [11,45]. Dietary protein and specific amino acids are involved in the control of gastric and intestinal motility and in pancreatic secretion, and are more potent in inducing satiety than carbohydrates or fats [55].

Gut peptides that regulate the digestive process and neuronal signaling in the central nervous system (CNS) regulate hunger and satiety [42]. Table 2 lists several peripheral hormones and their roles in the regulation of food intake [57].

Milk serum proteins are more potent stimulants of cholecystokinin (CCK) and GLP-1 than casein $[26,41,51]$. Among the peptides involved with whey protein, glycomacropeptide is an effective secretagogue of CCK [36]. CCK is a hormone secreted by I cells of the small intestine that has as one of its functions to modulate satiety [59]. However, Burton-Freeman [36] did not observe the effect of dietary whey protein on the increase of postprandial CCK levels in healthy subjects.

Table 2 Characteristics and functions of hormones related to appetite regulation

\begin{tabular}{ll}
\hline Hormones & Production and effects \\
\hline CCK & $\begin{array}{l}\text { Produced: duodenum } \\
\text { Effect: reduces appetite }\end{array}$ \\
GLP-1 & $\begin{array}{l}\text { Produced: mainly in distal intestine (L cells) } \\
\text { Effect: reduces appetite }\end{array}$ \\
Ghrelin & Produced: stomach \\
& Effect: stimulates appetite \\
GIP & Produced: K cells of the duodenum \\
& Effect: reduces appetite and potentiate insulin release \\
Leptin & Produced: mainly in adipose tissue \\
& Effect: suppress appetite \\
Uroguanylin [56] & Produced: intestinal epithelial cells \\
& Effect: reduces appetite
\end{tabular}

CCK: cholecystokinin, GLP-1: glucagon-like peptide 1, GIP: glucose-dependent insulinotropic peptide. Adapted: Pimentel \& Zemdegs, 2010 [57] and Pimentel et al. [58].
Therefore, we may to infer that probably a dose of whey was insufficient to stimulate the CCK.

Pal and Ellis [41] observed a significant decrease in glucose, appetite, and food intake, and an increase in serum insulin levels after the consumption of a drink containing $50 \mathrm{~g}$ of whey protein when compared to the consumption of a similar amount of protein tuna, turkey, or egg albumin. This study suggests a potential application of these foods in appetite control in both overweight and obese individuals.

Furthermore, other amino acids not described in this review are also associated with satiety, such as tryptophan, which is a precursor of serotonin and an important modulator of appetite [51].

Although the gut hormones are known by increase of anorexigenic hormones, also was observed that the leucine when injected directly in the central nervous system reduces the food intake and body weight [60]. Furthermore, Ropelle et al. [61] found that both leucine intracerebroventricular injection or high-protein diet decrease AMPK and increase mTOR phosphorylation in the CNS inhibiting the neuropeptide $\mathrm{Y}$ and stimulating the pro-opiomelanocortin expression, leading to reduction of food intake.

In summary, these findings suggesting that the aminoacids from whey protein may reduce the food intake via increase of gut hormones (CCK and GLP-1), and reduction of neuropeptide orexigenic (NPY) and increase of neuropeptide anorexigenic (POMC) in the hypothalamus.

\section{Anti-inflammatory actions}

Adipose tissue is an endocrine organ that releases hormones, cytokines, and others substances that tend to impair insulin sensitivity [55]. Obese individuals have increased secretion of adipocytokines by adipose tissue and macrophages [20].

Recently, Pal \& Ellis [41] observed in overweight and obese subjects that the supplementation of whey protein $(54 \mathrm{~g})$ for 12 weeks did not change the pro-inflammatory markers (IL-6, C-reactive protein-CRP, and TNF- $\alpha$ ). However, in D-galactosamine-induced hepatitis and liver fibrosis in rats, the consumption of whey protein strongly reduced the plasma levels of pro-inflammatory cytokines (IL-1 beta: 59\% and IL-6: 29\%) compared to the consumption of the same amount of casein [62].

Collectively, reduction of pro-inflammatory cytokines may be associated with reduction of body weight gain after consumption of whey protein and it aminoacids.

\section{Anti-oxidative stress actions}

Oxidative stress has been associated with MS, which is a disease recognized by inflammatory effects that are linked with the activation of reactive oxygen species (ROS) [63-65]. Nowadays, indicators that are more 
typically used in the evaluation of ROS are the endogenous antioxidant enzymes such as glutathione peroxidase, catalase, and superoxide dismutase, and other components such as malondialdehyde (MDA) and thiobarbituric acid reactive substances (TBARS) [63-66]. Recently, the administration of $100 \mathrm{mg} / \mathrm{kg}$ of body weight of whey protein in streptozotocin-induced diabetic rats was found to decrease several oxidative stress indicators, such as MDA, nitric oxide, and ROS concentrations; as well as reduction of pro-inflammatory cytokines (IL-1 $\beta$, TNF- $\alpha$, IL- 6 and IL-4) and increase glutathione levels [67]. Another study observed that rats fed high-carbohydrate, fat-free diets to induce fatty livers (nonalcoholic fatty liver model) plus orally administered whey protein $(0.15 \mathrm{~g} / \mathrm{d} / \mathrm{rat})$ for 28 days reduced MDA and increased glutathione levels [68].

Haraguchi et al. [19] found a protective effect against oxidative stress, mainly in the liver, and a beneficial effect on renal function in rats supplemented with whey protein plus a hypercholesterolemic diet, but they did not observe a reduction in serum cholesterol levels.

In human studies, beneficial effects in the reduction of oxidative stress after treatment with whey protein [6971]. Likewise, supplementation with $20 \mathrm{~g} / \mathrm{d}$ of whey protein isolate for 12 weeks in subjects with nonalcoholic steatohepatitis was found to increase the glutathione and total antioxidant capacities [70]. In healthy individuals, $45 \mathrm{~g} /$ day of whey protein supplementation in bar format for 14 days also increased lymphocyte glutathione levels [69]. De Aguilar-Nascimento et al. [71] studied patients with ischemic stroke that were fed via a nasogastric tube a diet with $35 \mathrm{kcal} / \mathrm{kg} / \mathrm{d}$ and $1.2 \mathrm{~g}$ of protein $/ \mathrm{kg} / \mathrm{d}$ containing whey protein and an observed reduction in IL-6 and an increase in glutathione levels after five days of supplementation.
Furthermore, several studies also shown in different models of oxidative stress that only whey protein or diets that contain this protein improve antioxidant function and decrease oxidative stress [72-75].

Collectively, these findings suggest that whey protein may act as a nutritional component to increase endogenous antioxidant enzymes (glutathione peroxidase, catalase, and superoxide dismutase) and to reduce oxidative stress markers (MDA, TBARS) jointly with low expression of pro-inflammatory cytokines (IL-1 $\beta$, IL- 6 and TNF- $\alpha$ ) in obese, diabetic or stroke patients.

\section{Commercialization and safety doses of whey protein}

Whey protein can be found in drinks, powder, protein bars, and milk. The main natural source of whey protein is bovine milk that has approximately $3.5 \%$ protein, of which $80 \%$ is casein and the remaining $20 \%$ is whey protein $[22,76]$. Whey protein concentrate also may include 29-89\% milk serum protein, and isolates should contain more than $90 \%$ whey protein [22]. In addition, whey protein can also be found in the form of hydrolysates. This form of whey protein hydrolysates aims to optimize the physical, chemical, and nutritional properties, improving the absorption of proteins [25].

According to the studies presented in this review, the amount of whey protein administered to adult humans is between $5.0-54.0 \mathrm{~g}$ at durations of approximately 12 weeks. Furthermore, no serious adverse effects were observed with whey protein supplementation. However, this supplementation must make part of a habitual diet.

\section{Future perspectives}

This review shows that whey protein may improve several risk factors for DM, obesity, hypertension, oxidative stress and MS (Figure 1). In addition, new studies

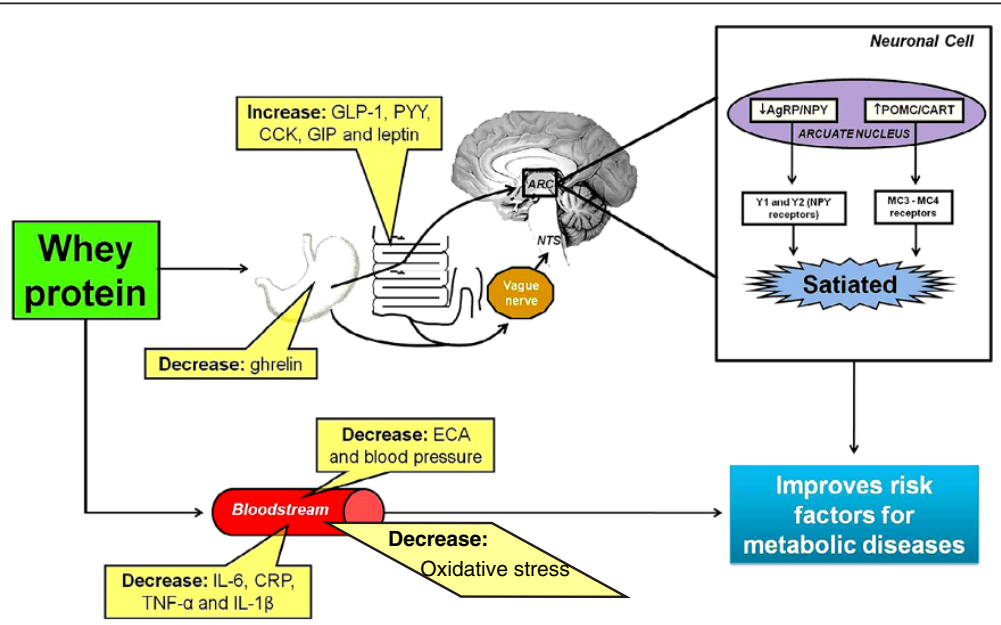

Figure 1 Main mechanisms of action of whey protein in protection of risk factors for metabolic diseases, such as obesity, type 2 diabetes mellitus, hypertension, oxidative stress and metabolic syndrome. 
suggest a relationship between consumption of whey protein source foods and oxidative stress, hepatoprotective effects, and increased resting energy expenditure.

Kume et al. [62] demonstrated a hepatoprotective effect of consumption of whey protein D-galactosamine-induced hepatitis and liver fibrosis in rats. There was a significant decrease in the activity of hepatic enzymes (AST: 92.5\%, ALT: 98\%, LDH: 65\%, hyaluronic acid: 60\%) after consumption of whey protein compared to casein.

In trained subjects, Hackney et al. [27] observed a significant increase $(5 \%)$ after 24 hours of resting energy expenditure with the consumption of $18 \mathrm{~g}$ of whey protein before of a single session of resistance training (70$75 \%$ of one repetition maximum) when compared to an intake of $19 \mathrm{~g}$ of carbohydrates. The authors speculate that this increase occurred by the increased availability of amino acids to skeletal muscle after whey protein intake. In addition, there was a decrease in respiratory coefficients in both the consumption of carbohydrates (5\%) and whey (6\%); this reduction indicates the increased oxidation of fat. Furthermore, more studies are needed to determine whether supplementation of whey protein plus a balanced diet and resistance training can increase the long-term increase in resting energy expenditure and improve body composition.

\section{Conclusions}

In summary, whey protein has an attractive effect on glucose metabolism control in healthy, overweight, obese, and insulin-resistant subjects. Moreover, whey protein assures a higher satiety; this effect is involved with the modulation of several gut hormones related to the reduction of food intake, with increased release of anorectic hormones, such as cholecystokinin, leptin, and GLP-1 and decreased release of the orexigenic hormone, ghrelin; and reduction of neuropeptide $\mathrm{Y}$ and increase of pro-opiomelanocortin in CNS. In addition, the reductions of expression of both inflammatory and oxidative stress markers, as well as the reduction in blood pressure, are also the main beneficial of risk factors for metabolic diseases.

\section{Competing interests}

The authors declare that they have no competing interests.

\section{Acknowledgements}

We would like to thank funding from the FAPESP.

\footnotetext{
Author details

'Departamento de Fisiologia e Biofísica, Instituto de Ciências Biomédicas, Universidade de São Paulo (USP), São Paulo/SP, Brazil. ${ }^{2}$ Laboratório de Bioquímica e Fisiologia do Exercício, Universidade do Extremo Sul Catarinense, Criciúma/SC, Brazil. ${ }^{3}$ Departamento de Patologia, Universidade Estadual Paulista (UNESP), Botucatu/SP, Brazil. "Departamento de Fisiologia, Universidade Federal de São Paulo (UNIFESP), São Paulo/SP, Brazil. ${ }^{5}$ Departamento de Psicobiologia, Universidade Federal de São Paulo (UNIFESP), São Paulo/SP, Brazil. ${ }^{6}$ Departamento de Clínica Médica, Universidade Estadual de Campinas (UNICAMP), Campinas/SP, MA: $13083-$ 970, Brazil.
}

\section{Authors' contributions}

GDP was the responsible by design of whole manuscript, GTDS and GDP wrote the paper, FSL, JCR, EPO, LMO, and RVS participated of choose and discussion of papers included. All authors read and approved the final manuscript.

Received: 14 February 2012 Accepted: 7 June 2012

Published: 7 June 2012

\section{References}

1. Giskes K, van Lenthe F, Avendano-Pabon M, Brug J: A systematic review of environmental factors and obesogenic dietary intakes among adults: are we getting closer to understanding obesogenic environments? Obes Rev 2011, 12:e95-e106.

2. Pimentel GD, Arimura ST, de Moura BM, Silva ME, de Sousa MV: Short-term nutritional counseling reduces body mass index, waist circumference, triceps skinfold and triglycerides in women with metabolic syndrome. Diabetol Metab Syndr 2010, 2:13.

3. WHO: Global strategy on diet, physical activity and health: obesity and overweight. Geneva: World Health Organization; 2012. http://www.who.int/ dietphysicalactivity/publications/facts/obesity/en/.

4. Misra A, Khurana L: Obesity-related non-communicable diseases: South Asians vs White Caucasians. Int J Obes (Lond) 2011, 35:167-187.

5. Gigante DP, Moura EC, Sardinha LM: Prevalence of overweight and obesity and associated factors, Brazil, 2006. Rev Saude Publica 2009, 43 (Suppl 2):83-89.

6. Rodrigues TC, Canani LH, Gross JL: Metabolic syndrome, insulin resistance and cardiovascular disease in type-1 diabetes mellitus. Arq Bras Cardiol 2010, 94:134-139.

7. Mortensen LS, Hartvigsen ML, Brader LJ, Astrup A, Schrezenmeir J, Holst JJ, Thomsen C, Hermansen K: Differential effects of protein quality on postprandial lipemia in response to a fat-rich meal in type 2 diabetes: comparison of whey, casein, gluten, and cod protein. Am J Clin Nutr 2009, 90:41-48.

8. de Oliveira EP, Manda RM, Torezan GA, Corrente JE, Burini RC: Dietary, anthropometric, and biochemical determinants of plasma high-density lipoprotein-cholesterol in free-living adults. Cholesterol 2011, 2011:851750.

9. Takahashi MM, de Oliveira EP, Moreto F, Portero-McLellan KC, Burini RC: Association of dyslipidemia with intakes of fruit and vegetables and the body fat content of adults clinically selected for a lifestyle modification program. Arch Latinoam Nutr 2010, 60:148-154.

10. Frestedt JL, Zenk JL, Kuskowski MA, Ward LS, Bastian ED: A whey-protein supplement increases fat loss and spares lean muscle in obese subjects: a randomized human clinical study. Nutr Metab (Lond) 2008, 5:8.

11. Solah VA, Kerr DA, Adikara CD, Meng X, Binns CW, Zhu K, Devine A, Prince $R L$ : Differences in satiety effects of alginate- and whey protein-based foods. Appetite 2010, 54:485-491.

12. Pimentel GD, Portero-McLellan KC, de Oliveira EP, Spada AP, Oshiiwa M, Zemdegs JC, Barbalho SM: Long-term nutrition education reduces several risk factors for type 2 diabetes mellitus in Brazilians with impaired glucose tolerance. Nutr Res 2010, 30:186-190.

13. Pilvi TK, Harala S, Korpela R, Mervaala EM: Effects of high-calcium diets with different whey proteins on weight loss and weight regain in highfat-fed C57BL/6 J mice. Br J Nutr 2009, 102:337-341.

14. Bowen J, Noakes M, Clifton PM: Appetite regulatory hormone responses to various dietary proteins differ by body mass index status despite similar reductions in ad libitum energy intake. J Clin Endocrinol Metab 2006, 91:2913-2919.

15. Petersen BL, Ward LS, Bastian ED, Jenkins AL, Campbell J, Vuksan V: A whey protein supplement decreases post-prandial glycemia. Nutr J 2009, 8:47.

16. Gunnarsson PT, Winzell MS, Deacon CF, Larsen MO, Jelic K, Carr RD, Ahren $B$ : Glucose-induced incretin hormone release and inactivation are differently modulated by oral fat and protein in mice. Endocrinology 2006, 147:3173-3180.

17. Takasaki K, Nakajima T, Ueno K, Nomoto Y, Higo K: Effects of combination treatment with dipeptidyl peptidase IV inhibitor and sulfonylurea on glucose levels in rats. J Pharmacol Sci 2004, 95:291-293.

18. Whey protein: Monograph. Altern Med Rev 2008, 13:341-347.

19. Haraguchi FK, Pedrosa ML, de Paula H, dos Santos RC, Silva ME: Influência das proteínas do soro sobre enzimas hapáticas, perfil 
lipídico e formação óssea de ratos hipercolesterolêmicos. Rev Nutr 2009, 22:517-525.

20. Luhovyy BL, Akhavan T, Anderson GH: Whey proteins in the regulation of food intake and satiety. J Am Coll Nutr 2007, 26:704S-712S.

21. Haraguchi FK, de Abreu WC, de Paula H: Proteínas do soro do leite: composição, propriedades nutricionais, aplicações no esporte $e$ benefícios para a saúde humana. Rev Nutr 2006, 19:479-488.

22. Hulmi JJ, Lockwood CM, Stout JR: Effect of protein/essential amino acids and resistance training on skeletal muscle hypertrophy: A case for whey protein. Nutr Metab (Lond) 2010, 7:51.

23. Pal $\mathrm{S}$, Ellis $\mathrm{V}, \mathrm{Ho} \mathrm{S}$ : Acute effects of whey protein isolate on cardiovascular risk factors in overweight, post-menopausal women. Atherosclerosis 2010, 212:339-344.

24. Barnett MP, Phillips AR, Harris PM, Cooper GJ: Impaired insulin secretion in perfused pancreases isolated from offspring of female rats fed a low protein whey-based diet. Jop 2008, 9:477-488.

25. Pacheco MTB, Dias NFG, Baldini VLS, Tanikawa C, Sgarbieri VCS: Propriedades funcionais de hidrolisados obtidos a partir de concentrados protéicos de soro de leite. Ciênc Tecnol Aliment 2005, 25:333-338.

26. Pal $S$, Ellis $V$ : The acute effects of four protein meals on insulin, glucose, appetite and energy intake in lean men. Br J Nutr 2010, 104:1241-1248.

27. Hackney KJ, Bruenger AJ, Lemmer JT: Timing protein intake increases energy expenditure $24 \mathrm{~h}$ after resistance training. Med Sci Sports Exerc 2010, 42:998-1003.

28. Lan-Pidhainy $X$, Wolever TM: The hypoglycemic effect of fat and protein is not attenuated by insulin resistance. Am J Clin Nutr 2010, 91:98-105.

29. Pilvi TK, Korpela R, Huttunen M, Vapaatalo H, Mervaala EM: High-calcium diet with whey protein attenuates body-weight gain in high-fat-fed C57BI/6 J mice. Br J Nutr 2007, 98:900-907.

30. Muro Urista C, Alvarez Fernandez R, Riera Rodriguez F, Arana Cuenca A, Tellez Jurado A: Review: Production and functionality of active peptides from milk. Food Sci Technol Int 2011, 17:293-317.

31. Graf S, Egert S, Heer M: Effects of whey protein supplements on metabolism: evidence from human intervention studies. Curr Opin Clin Nutr Metab Care 2011, 14:569-580.

32. Gilbert JA, Bendsen NT, Tremblay A, Astrup A: Effect of proteins from different sources on body composition. Nutr Metab Cardiovasc Dis 2011, 21(Suppl 2):B16-31.

33. Dougkas A, Reynolds CK, Givens ID, Elwood PC, Minihane AM: Associations between dairy consumption and body weight: a review of the evidence and underlying mechanisms. Nutr Res Rev 2011, :1-24

34. Madureira AR, Tavares T, Gomes AM, Pintado ME, Malcata FX: Invited review: physiological properties of bioactive peptides obtained from whey proteins. J Dairy Sci 2010, 93:437-455.

35. Baer DJ, Stote KS, Paul DR, Harris GK, Rumpler W, Clevidence BA: Whey protein but not soy protein supplementation alters body weight and composition in free-living overweight and obese adults. J Nutr 2011, 141:1489-1494.

36. Burton-Freeman BM: Glycomacropeptide (GMP) is not critical to wheyinduced satiety, but may have a unique role in energy intake regulation through cholecystokinin (CCK). Physiol Behav 2008, 93:379-387.

37. Pichon L, Potier M, Tome D, Mikogami T, Laplaize B, Martin-Rouas C, Fromentin G: High-protein diets containing different milk protein fractions differently influence energy intake and adiposity in the rat. $\mathrm{Br} J$ Nutr 2008, 99:739-748.

38. Pilvi TK, Storvik M, Louhelainen M, Merasto S, Korpela R, Mervaala EM: Effect of dietary calcium and dairy proteins on the adipose tissue gene expression profile in diet-induced obesity. J Nutrigenet Nutrigenomics 2008, 1:240-251.

39. Pal S, Ellis V, Dhaliwal S: Effects of whey protein isolate on body composition, lipids, insulin and glucose in overweight and obese individuals. Br J Nutr 2010, 104:716-723.

40. Kasim-Karakas SE, Cunningham WM, Tsodikov A: Relation of nutrients and hormones in polycystic ovary syndrome. Am J Clin Nutr 2007, 85:688-694.

41. Pal S, Ellis V: The chronic effects of whey proteins on blood pressure, vascular function, and inflammatory markers in overweight individuals. Obesity (Silver Spring) 2010, 18:1354-1359.

42. Pimentel GD, Mota JF, Oyama LM: Oxyntomodulin and obesity. Rev Nutr 2009, 22:727-737.

43. Pimentel GD, Dornellas AP, Rosa JC, Lira FS, Cunha CA, Boldarine VT, de Souza GI, Hirata AE, Nascimento CM, Oyama LM, et al: High-fat diets rich in soy or fish oil distinctly alter hypothalamic insulin signaling in rats. J Nutr Biochem 2012, 23:822-8.

44. Carvalheira JB, Ribeiro EB, Araujo EP, Guimaraes RB, Telles MM, Torsoni M, Gontijo JA, Velloso LA, Saad MJ: Selective impairment of insulin signalling in the hypothalamus of obese Zucker rats. Diabetologia 2003, 46:1629-1640.

45. Ropelle ER, Flores MB, Cintra DE, Rocha GZ, Pauli JR, Morari J, de Souza CT, Moraes JC, Prada PO, Guadagnini D, et al: IL-6 and IL-10 anti-inflammatory activity links exercise to hypothalamic insulin and leptin sensitivity through IKKbeta and ER stress inhibition. PLOS Biol 2010, 8.

46. Frid AH, Nilsson M, Holst JJ, Bjorck IM: Effect of whey on blood glucose and insulin responses to composite breakfast and lunch meals in type 2 diabetic subjects. Am J Clin Nutr 2005, 82:69-75.

47. Li C, Chen P, Palladino A, Narayan S, Russell LK, Sayed S, Xiong G, Chen J, Stokes D, Butt YM, et al: Mechanism of hyperinsulinism in short-chain 3hydroxyacyl-CoA dehydrogenase deficiency involves activation of glutamate dehydrogenase. J Biol Chem 2010, 285:31806-31818.

48. Mortensen LS, Holmer-Jensen J, Hartvigsen ML, Jensen VK, Astrup A, de Vrese M, Holst JJ, Thomsen C, Hermansen K: Effects of different fractions of whey protein on postprandial lipid and hormone responses in type 2 diabetes. Eur J Clin Nutr 2012, In press.

49. Santoro S, Velhote MCP, Manzoni CE, Mechenas ASG, Strassmann V, Scheinberg $V$ : Adaptação digestiva: Uma nova proposta cirúrgica para tratar a obesidade com base em fisiologia e evolução. Einstein 2003, 1:95-98.

50. Mannucci E, Pala L, Ciani S, Bardini G, Pezzatini A, Sposato I, Cremasco F, Ognibene A, Rotella CM: Hyperglycaemia increases dipeptidyl peptidase IV activity in diabetes mellitus. Diabetologia 2005, 48:1168-1172.

51. Veldhorst MA, Nieuwenhuizen AG, Hochstenbach-Waelen A, van Vught AJ, Westerterp KR, Engelen MP, Brummer RJ, Deutz NE, Westerterp-Plantenga MS: Dose-dependent satiating effect of whey relative to casein or soy. Physiol Behav 2009, 96:675-682.

52. Pinto LC, Ricardo ED, Leitao CB, Kramer CK, Zanatta CM, Gross JL, Canani LH: Inadequate blood pressure control in patients with type 2 diabetes mellitus. Ara Bras Cardiol 2010, 94:651-655.

53. Takahashi MM, de Oliveira EP, de Carvalho AL, de Souza Dantas LA, Burini FH, Portero-McLellan KC, Burini RC: Metabolic syndrome and dietary components are associated with coronary artery disease risk score in free-living adults: a cross-sectional study. Diabetol Metab Syndr 2011, 3:7.

54. Lee YM, Skurk T, Hennig M, Hauner H: Effect of a milk drink supplemented with whey peptides on blood pressure in patients with mild hypertension. Eur J Nutr 2007, 46:21-27.

55. Tome D, Schwarz J, Darcel N, Fromentin G: Protein, amino acids, vagus nerve signaling, and the brain. Am J Clin Nutr 2009, 90:838S-843S.

56. Valentino MA, Lin JE, Snook AE, Li P, Kim GW, Marszalowicz G, Magee MS, Hyslop T, Schulz S, Waldman SA: A uroguanylin-GUCY2C endocrine axis regulates feeding in mice. J Clin Invest 2011, 121:3578-3588.

57. Pimentel GD, Zemdegs JC: Foods and nutrients modulates the release of anorexigenic gastrointestinal hormones. Acta Med Port 2010, 23:891-900.

58. Pimentel GD, Micheletti TO, Pace F, Rosa JC, Santos RV, Lira FS: Gut-central nervous system axis is a target for nutritional therapies. Nutr J 2012, 11:22

59. Foltz M, Ansems P, Schwarz J, Tasker MC, Lourbakos A, Gerhardt CC: Protein hydrolysates induce CCK release from enteroendocrine cells and act as partial agonists of the CCK1 receptor. J Agric Food Chem 2008, 56:837-843.

60. Cota D, Proulx K, Smith KA, Kozma SC, Thomas G, Woods SC, Seeley RJ: Hypothalamic mTOR signaling regulates food intake. Science 2006 312:927-930.

61. Ropelle ER, Pauli JR, Fernandes MF, Rocco SA, Marin RM, Morari J, Souza KK, Dias MM, Gomes-Marcondes MC, Gontijo JA, et al: A central role for neuronal AMP-activated protein kinase (AMPK) and mammalian target of rapamycin (mTOR) in high-protein diet-induced weight loss. Diabetes 2008, 57:594-605.

62. Kume H, Okazaki K, Sasaki H: Hepatoprotective effects of whey protein on D-galactosamine-induced hepatitis and liver fibrosis in rats. Biosci Biotechnol Biochem 2006, 70:1281-1285.

63. Heilbronn LK, de Jonge L, Frisard MI, DeLany JP, Larson-Meyer DE, Rood J, Nguyen T, Martin CK, Volaufova J, Most MM, et al: Effect of 6-month calorie restriction on biomarkers of longevity, metabolic adaptation, and oxidative stress in overweight individuals: a randomized controlled trial. JAMA 2006, 295:1539-1548. 
64. Cruz-Guilloty F, Perez VL: Molecular medicine: Defence against oxidative damage. Nature 2011, 478:42-43.

65. Van Gaal LF, Mertens IL, De Block CE: Mechanisms linking obesity with cardiovascular disease. Nature 2006, 444:875-880.

66. Mercer JR, Yu E, Figg N, Cheng KK, Prime TA, Griffin JL, Masoodi M, VidalPuig A, Murphy MP, Bennett MR: The mitochondria-targeted antioxidant MitoQ decreases features of the metabolic syndrome in ATM+/-/ApoE -1- mice. Free Radic Biol Med 2012, 52:841-849.

67. Ebaid H, Salem A, Sayed A, Metwalli A: Whey protein enhances normal inflammatory responses during cutaneous wound healing in diabetic rats. Lipids Health Dis 2011, 10:235.

68. Hamad EM, Taha SH, Abou Dawood AG, Sitohy MZ, Abdel-Hamid M: Protective effect of whey proteins against nonalcoholic fatty liver in rats. Lipids Health Dis 2011, 10:57.

69. Zavorsky GS, Kubow S, Grey V, Riverin V, Lands LC: An open-label doseresponse study of lymphocyte glutathione levels in healthy men and women receiving pressurized whey protein isolate supplements. Int $\rfloor$ Food Sci Nutr 2007, 58:429-436.

70. Chitapanarux T, Tienboon P, Pojchamarnwiputh S, Leelarungrayub D: Openlabeled pilot study of cysteine-rich whey protein isolate supplementation for nonalcoholic steatohepatitis patients. J Gastroenterol Hepatol 2009, 24:1045-1050.

71. de Aguilar-Nascimento JE, Prado Silveira BR, Dock-Nascimento DB: Early enteral nutrition with whey protein or casein in elderly patients with acute ischemic stroke: a double-blind randomized trial. Nutrition 2011, 27:440-444.

72. Xu R, Liu N, Xu X, Kong B: Antioxidative effects of whey protein on peroxide-induced cytotoxicity. J Dairy Sci 2011, 94:3739-3746.

73. Takayanagi T, Sasaki H, Kawashima A, Mizuochi Y, Hirate H, Sugiura T, Azami T, Asai K, Sobue K: A new enteral diet, MHN-02, which contains abundant antioxidants and whey peptide, protects against carbon tetrachlorideinduced hepatitis. JPEN J Parenter Enteral Nutr 2011, 35:516-522.

74. Abdel-Aziem SH, Hassan AM, Abdel-Wahhab MA: Dietary supplementation with whey protein and ginseng extract counteracts oxidative stress and DNA damage in rats fed an aflatoxin-contaminated diet. Mutat Res 2011, 723:65-71.

75. Gad AS, Khadrawy YA, El-Nekeety AA, Mohamed SR, Hassan NS, AbdelWahhab MA: Antioxidant activity and hepatoprotective effects of whey protein and Spirulina in rats. Nutrition 2011, 27:582-589.

76. Yalcin AS: Emerging therapeutic potential of whey proteins and peptides. Curr Pharm Des 2006, 12:1637-1643.

\section{doi:10.1186/1476-511X-11-67}

Cite this article as: Sousa et al:: Dietary whey protein lessens several risk factors for metabolic diseases: a review. Lipids in Health and Disease 2012 11:67.

\section{Submit your next manuscript to BioMed Central and take full advantage of:}

- Convenient online submission

- Thorough peer review

- No space constraints or color figure charges

- Immediate publication on acceptance

- Inclusion in PubMed, CAS, Scopus and Google Scholar

- Research which is freely available for redistribution 